\title{
Type III Hyperlipoproteinemic Phenotype in Transgenic Mice Expressing Dysfunctional Apolipoprotein E
}

Sergio Fazio, Ya-Li Lee, Zhong-Sheng Ji, and Stanley C. Rall, Jr. Gladstone Institute of Cardiovascular Disease, Cardiovascular Research Institute, University of California, San Francisco, California $94141-9100$

\begin{abstract}
Transgenic mice were prepared that expressed a dysfunctional apo $\mathrm{E}$ variant, apo E(Arg-112, Cys-142), which is associated with dominant inheritance of type III hyperlipoproteinemia (type III HLP) in humans. Among eight founder mice, plasma apo E(Arg-112, Cys-142) levels varied 100-fold and directly correlated with plasma cholesterol and triglyceride levels. On a normal chow diet, mice expressing high levels (>70 mg/dl) of the dysfunctional apo $\mathbf{E}$ had grossly elevated plasma lipids, with cholesterol levels of up to $410 \mathrm{mg} / \mathrm{dl}$ and triglyceride levels of up to $1,210 \mathrm{mg} / \mathrm{dl}$. Upon agarose electrophoresis, plasma from these mice demonstrated $\beta$-very low density lipoproteins ( $\beta$-VLDL). Mice expressing low $(<2.5 \mathrm{mg} / \mathrm{dl}$ ) or intermediate $(21 \mathrm{mg} / \mathrm{dl})$ levels of the apo $E$ variant had much less severe hyperlipidemia and did not have $\beta$-VLDL. Although the transgenic mouse $\beta$-VLDL were enriched in cholesteryl esters compared with normal mouse VLDL, they were not as cholesterol enriched as human $\beta$-VLDL from type III HLP subjects. Transgenic mouse $\beta$-VLDL injected into normal mice were cleared from plasma at a significantly slower rate than normal mouse VLDL, demonstrating the impaired catabolism of $\beta$ VLDL. Thus, transgenic mice expressing high levels of the dysfunctional apo E(Arg-112, Cys-142) variant have many characteristics of the human type III HLP phenotype and appear to be a suitable animal model for this disorder. (J. Clin. Invest. 1993. 92:1497-1503.) Key words: apolipoprotein $\mathbf{E}$ • cholesterol $\bullet$ hyperlipidemia $\bullet$ transgenic mice $\bullet \beta$-very low density lipoproteins
\end{abstract}

\section{Introduction}

Type III hyperlipoproteinemia (type III HLP) ${ }^{1}$ is a genetic disorder of lipid metabolism in humans that predisposes affected subjects to premature development of atherosclerosis (1). Affected subjects demonstrate both hypercholesterolemia and hypertriglyceridemia, owing to accumulation in the plasma of

Address correspondence to Dr. Sergio Fazio, Gladstone Institute of Cardiovascular Disease, P.O. Box 419100, San Francisco, CA 941419100.

Received for publication 15 December 1992 and in revised form 17 March 1993.

1. Abbreviations used in this paper: CETP, cholesteryl ester transfer protein; type III HLP, type III hyperlipoproteinemia.

J. Clin. Invest.

(c) The American Society for Clinical Investigation, Inc.

$0021-9738 / 93 / 09 / 1497 / 07 \$ 2.00$

Volume 92, September 1993, 1497-1503 abnormal lipoproteins: $\beta$-very low density lipoproteins $(\beta$ VLDL), which are remnants of both intestinal chylomicrons and hepatic VLDL. Type III HLP can be caused either by the expression of any of several receptor binding-defective variants of apo $E(1,2)$ or by apo E deficiency $(3,4)$. Apo $E$ normally functions as a ligand for remnant uptake by lipoprotein receptors (5). In type III HLP, abnormal apo E causes impaired receptor-mediated lipoprotein catabolism that results in $\beta$-VLDL accumulation (1).

Most subjects with type III HLP are homozygous for apo E2(Cys-158), one of the three major polymorphic isoforms of apo E (1). Several rare variants of apo $E$ that are associated with type III HLP have also been described (2). In most of these latter instances, heterozygosity for the rare variant apo $\mathrm{E}$ is sufficient for expression of type III HLP, without the need for exacerbating factors usually required for type III HLP expression in apo E2 (Cys-158) homozygotes $(1,2)$. One of these rare apo E variants, apo E(Arg-112, Cys-142), has been described in a family in which type III HLP occurs in four generations (6, 7). All seven affected family members are heterozygous for apo $\mathrm{E}$ (Arg-112, Cys-142) (7); thus, the phenotype is transmitted as a dominant characteristic. In an attempt to explain the reason(s) for the dominant inheritance of type III HLP in apo E(Arg-112, Cys-142) subjects, Horie et al. studied some properties of this apo $E$ variant that had been produced in bacteria by recombinant DNA techniques (8). It was suggested that two properties of apo E(Arg-112, Cys-142), in addition to its receptor binding defect, specifically contributed to dominant inheritance of type III HLP: its tendency to associate preferentially with triglyceride-rich lipoproteins, and its reduced heparin binding affinity. Both of these properties could lead to selective accumulation of the dysfunctional apo $\mathrm{E}$ in $\beta$-VLDL and, in turn, to dominant inheritance. Indeed, apo E(Arg-112, Cys142) was shown to predominate over normal apo E3 by a $3: 1$ ratio in the $\beta$-VLDL of an affected subject (8).

Although studies of type III HLP have been insightful, an animal model of the disorder would be useful. Therefore, we created transgenic mice expressing the human apo $\mathrm{E}$ variant, apo $\mathrm{E}$ (Arg-112, Cys-142). The rationale for selecting this particular variant was twofold: First, since the transgenic apo $\mathrm{E}$ would be expressed on a background of endogenous mouse apo $\mathrm{E}$, the likelihood of obtaining a type III HLP phenotype in mice would be greater with a variant known to yield type III HLP in humans coexpressing normal apo E3. Second, the apo E(Arg112 , Cys-142) variant is more like mouse apo $\mathrm{E}$ in that it contains arginine at the polymorphic site, residue 112 (mouse apo E contains arginine at the equivalent position, residue 104). The presence of arginine at this position confers upon human apo E a preference for association with triglyceride-rich lipoproteins $(9,10)$.

Mouse models of lipoprotein metabolism, using both transgenic and gene targeting methodologies, are yielding important 
new information. In particular, the recent creation of transgenic mice overexpressing rat apo $\mathrm{E}(11,12)$ and of null apo $\mathrm{E}$ mice by gene targeting $(13,14)$ has suggested the critical importance of apo $\mathrm{E}$ in lipoprotein metabolism in mice. While transgenic mice overexpressing rat apo E demonstrate reduced VLDL levels, the null apo E mice develop severe hypercholesterolemia and premature atherosclerosis, both on normal chow diets. Several of the characteristics of null apo $\mathrm{E}$ mice mimic human apo E deficiency and therefore these mice seem to be a reasonable model of that disorder. Likewise, in this report we demonstrate that mice expressing high levels of apo $\mathrm{E}$ (Arg112, Cys-142) spontaneously develop hyperlipidemia and accumulate the abnormal lipoproteins, $\beta$-VLDL, the hallmark characteristic of the disorder in humans.

\section{Methods}

DNA constructs. Two apo E(Arg-112, Cys-142) constructs were prepared for microinjection into mouse embryos. One contained a 3.8-kb SphI-BamHI fragment from the human apo $\mathrm{E} / \mathrm{CI} / \mathrm{CI}^{\prime} / \mathrm{CII}$ gene locus that directs high levels of liver expression of apo $\mathrm{E}$ and apo $\mathrm{CI}$ in transgenic mice $(15,16)$. This element, provided by Dr. S. Simonet and Dr. J. Taylor, was ligated 5 ' to the parent HEG1 apo E gene construct (17). The second construct contained $5 \mathrm{~kb}$ of the $5^{\prime}$ flanking region of the human apo A-I gene fused to exon one of the human apo $E$ gene. This construct, provided by Dr. E. Spangler and Dr. E. Rubin, also directs high-level liver expression of apo E (Spangler, E., J. Verstuyft, and E. Rubin, manuscript submitted for publication). Into these two constructs were introduced the appropriate mutations, as previously described for a different vector (8), yielding the vectors termed pHEG1LE142 and pAIE142, respectively.

Preparation of transgenic mice. Transgenic mice were prepared by DNX Corp. (Princeton, NJ) commercial transgenic services by microinjection of either of the above constructs into C57BL/6 $\times$ SJL F2 hybrid embryos. At 4-5 wk of age, the resulting mice were weaned and shipped to San Francisco, where they were maintained on a normal chow diet. Analysis for presence of the transgene was performed by Southern blotting of $10 \mu \mathrm{g}$ of tail DNA using a human apo E cDNA probe (18) and by immunoblotting of $1 \mu$ l of plasma using a humanspecific anti-apo E polyclonal antisera $(17,19)$. For pHEG1LE142, 2 of 21 animals were positive; for pAIE142, 6 of 56 were positive. The transgene copy number was estimated by densitometric comparison with Southern blot of an equivalent amount of DNA from HepG2 cells. Human apo E plasma concentrations were determined by a radioimmunoassay specific for human apo E (10).

Preparation of total RNA and ribonuclease protection assay. Total cellular RNA was isolated and analyzed as described by Simonet et al. (15). Briefly, a 192-base antisense RNA probe for human apo E mRNA was transcribed using bacteriophage T3 RNA polymerase in the presence of $\left[{ }^{32} \mathrm{P}\right]$ UTP from a cDNA fragment that had been cloned in Bluescript vector (Stratagene, La Jolla, CA). Hybridization of $1 \mu \mathrm{g}$ of tissue RNA with $3 \times 10^{5} \mathrm{cpm}$ of labeled probe was carried out for 5 min at $85^{\circ} \mathrm{C}$, followed by RNAse digestion for $1 \mathrm{~h}$ at $37^{\circ} \mathrm{C}$. Protected fragments were analyzed in $6 \%$ polyacrylamide gels containing $7 \mathrm{M}$ urea, followed by radiography of the dried gel.

Lipoprotein separation and analysis. Blood was taken from the tails of 6-8-wk-old mice during the light cycle when they were not eating. Plasma was obtained by centrifugation at $14,000 \mathrm{rpm}$ (microfuge) for $20 \mathrm{~min}$ at $4^{\circ} \mathrm{C}$. Plasma samples $(50-200 \mu \mathrm{l})$ were chromatographed on a Superose 6 column as previously described $(8,19)$. In some cases, Superose 6 fractions corresponding to the major lipoprotein classes (fractions 15-18, VLDL; 19-22, intermediate density lipoproteins (IDL); 23-26, low density lipoproteins (LDL) and high density lipoproteins $\left._{1}\left(\mathrm{HDL}_{1}\right) ; 27-32, \mathrm{HDL}\right)$ were pooled and concentrated to 200 $\mu \mathrm{l}$, and $5-\mu \mathrm{l}$ aliquots were run on precast $1 \%$ agarose gels for $35 \mathrm{~min}$ at $90 \mathrm{~V}(16,19)$. The gels were either dried for lipid staining with Fat Red
7B or blotted onto nitrocellulose and incubated consecutively with two antisera, one for detection of human apo $\mathrm{E}(8)$ and the other for mouse apo $E(20)$. The human-specific antiserum against apo $E$ showed very little crossreactivity with mouse apo $\mathrm{E}$. In dilution assays using this antiserum, mouse apo $\mathrm{E}$ had a reaction intensity 20 -fold lower than that of human apo E. ${ }^{2}$ For detection of mouse apo E, a rat-specific anti-apo $E$ antiserum (20) was used that recognized mouse apo $E$ but did not crossreact with human apo $\mathrm{E}^{2}$

Ultracentrifugation was performed on either plasma or pooled $\mathrm{Su}$ perose 6 fractions at $d=1.006 \mathrm{~g} / \mathrm{ml}$ in a model TL- 100 tabletop centrifuge (Beckman Instruments, Inc., Fullerton, CA) for $2.5 \mathrm{~h}$-i 100,000 $\mathrm{rpm}$ at $10^{\circ} \mathrm{C}$. The resulting $200 \mu \mathrm{l} d<1.006 \mathrm{~g} / \mathrm{ml}$ top fraction was either analyzed by agarose electrophoresis or delipidated by incubation in sample application buffer, and then electrophoresed at $80 \mathrm{~V}$ overnight on 5-20\% SDS-polyacrylamide gradient gels. Gels were either stained with Coomassie brilliant blue R250 or transferred to nitrocellulose for immunoblotting.

Cholesterol and triglycerides were measured on a $50-\mu$ l plasma sample or a $100-\mu 1$ sample of each $500-\mu 1$ Superose 6 fraction by a colorimetric method (8), adapted for use with a microplate reader. Cholesteryl ester contents of VLDL and $\beta$-VLDL fractions were determined by difference after measurement of total cholesterol by an enzymatic method (Boehringer Mannheim Corp., Indianapolis, IN) and of free cholesterol with a kit (Free Cholesterol C; Wako, Osaka, Japan).

In vivo metabolism studies. Lipoproteins of $d<1.006 \mathrm{~g} / \mathrm{ml}$ were obtained from $100 \mu \mathrm{l}$ of transgenic mouse plasma or $2 \mathrm{ml}$ of pooled nontransgenic mouse plasma and iodinated by the method of Bilheimer et al. (21). Specific activities ranged from 200 to $400 \mathrm{cpm} / \mathrm{ng} .5$ $\mu \mathrm{g}$ of VLDL protein in $100 \mu \mathrm{l}$ of saline was injected into the tail vein of normal mice. At each of three time points after injection (i.e., 5, 10, or $15 \mathrm{~min}$ ) three to six mice were killed, blood was collected via heart puncture, and the liver was removed. Radioactivity of portions of plasma and liver was determined in a $\gamma$ counter and normalized to total plasma volume (defined as $3.5 \%$ of body weight) or total liver weight (22).

\section{Results}

Eight founder mice expressing the apo E(Arg-112, Cys-142) variant were identified ( Table I). Although the transgene copy number varied only about sixfold, plasma levels of apo E(Arg112 , Cys-142) varied 100 -fold, from about half the endogenous mouse apo $\mathrm{E}$ level to a 50-fold excess. In female founders on a normal chow diet there was a strong direct correlation between the plasma levels of the human apo $\mathrm{E}$ and plasma cholesterol (linear regression analysis, $r=0.96$ ) and a weaker correlation between apo $\mathrm{E}$ and plasma triglycerides $(r=0.80)$.

Liver-specific expression of the two constructs was verified by RNAse protection assays. Several tissues from mice expressing either pHEG1LE142 or pAIE142 were examined. As shown in Fig. 1, both constructs were expressed only in the liver, producing the same 192-bp protected fragment as HepG2 cells, which served as the positive control. These results confirmed previous observations with similar constructs of normal human apo E (see Methods).

Plasma lipoproteins from several of the transgenic lines expressing low, intermediate, or high levels of the apo $\mathrm{E}$ variant were analyzed by Superose 6 chromatography. Lipoproteins from founders expressing high levels of the human apo $\mathrm{E}$ variant $(74$ or $91 \mathrm{mg} / \mathrm{dl}$ ) showed a dramatic redistribution of plasma cholesterol compared with lipoprotein cholesterol of

2. Fazio, S., Y. Horie, S. Simonet, K. Weisgraber, J. Taylor, and S. Rall, manuscript submitted for publication. 


\begin{tabular}{|c|c|c|c|c|c|c|}
\hline \multirow[b]{2}{*}{ Founder } & \multirow[b]{2}{*}{ Construct } & \multirow[b]{2}{*}{ Sex } & \multirow[b]{2}{*}{$\begin{array}{l}\text { Transgene } \\
\text { copy no. }\end{array}$} & \multicolumn{3}{|c|}{ Plasma concentrations } \\
\hline & & & & $\begin{array}{l}\text { Human } \\
\text { apo E }\end{array}$ & TC & TG \\
\hline & & & & \multicolumn{3}{|c|}{$m g / d l$} \\
\hline 1 & pHEG1LE142 & $\mathbf{F}$ & 9 & 74 & 211 & 491 \\
\hline 2 & pHEG1LE142 & $\mathrm{F}$ & 4 & 21 & 112 & 256 \\
\hline 3 & pAIE142 & $\mathrm{F}$ & 22 & 288 & 410 & 1,190 \\
\hline 4 & pAIE142 & $\mathbf{F}$ & 9 & 122 & 305 & 1,210 \\
\hline 5 & pAIE142 & $\mathrm{F}$ & 7 & 91 & 210 & 1,060 \\
\hline 6 & pAIE142 & $\mathbf{F}$ & 19 & 34 & 104 & 393 \\
\hline \multicolumn{2}{|c|}{ Nontransgenics $(n=7)$} & $\mathrm{F}$ & - & - & $73 \pm 23$ & $99 \pm 27$ \\
\hline 7 & pAIE142 & $\mathbf{M}$ & 10 & 7 & 86 & 236 \\
\hline 8 & pAIE142 & $\mathbf{M}$ & ND & 2.5 & 118 & 250 \\
\hline \multicolumn{2}{|c|}{ Nontransgenics $(n=7)$} & $\mathbf{M}$ & - & - & $102 \pm 22$ & $137 \pm 62$ \\
\hline
\end{tabular}

ND, not determined; TC, total plasma cholesterol; TG, total plasma triglycerides.

nontransgenic littermates. (Fig. $2 A$ shows Superose 6 chromatography of plasma from founder 1.) Most of the cholesterol was in the VLDL fraction rather than in the HDL fraction, which contained $\sim 80 \%$ of the cholesterol in normal mice (Fig. $2 A$ ). HDL cholesterol in the transgenic mouse was reduced $\sim 40 \%$ compared with that of its nontransgenic littermate. In both transgenic and nontransgenic mice $>90 \%$ of the triglycerides were in the VLDL fraction, although the absolute triglyceride level was considerably higher in transgenics (data not shown). Analysis of $10 \mathrm{Fl}$ offspring of founder 1 confirmed the above results. The plasma lipids for the five transgenics ( three males, two females) were $229 \pm 71 \mathrm{mg} / \mathrm{dl}$ for cholesterol and $741 \pm 409 \mathrm{mg} / \mathrm{dl}$ for triglycerides, compared with $79 \pm 16 \mathrm{mg} / \mathrm{dl}$ for cholesterol and $101 \pm 10 \mathrm{mg} / \mathrm{dl}$ for triglycer-

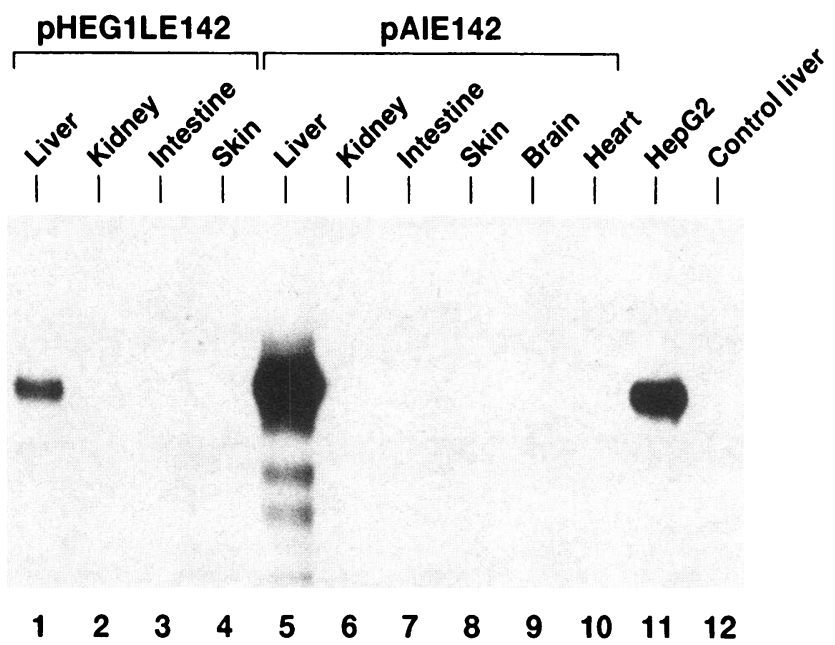

Figure 1. Ribonuclease protection assay of human apo E mRNA in tissues of transgenic mice. RNA was isolated from the indicated tissues of transgenic mice expressing apo $E$ derived either from the construct pHEG1LE142 or from pAIE142. RNA from HepG2 cells (lane 11) served as the positive control, yielding the same 192-bp protected fragment as the livers of the transgenic mice (lanes $l$ and 5). RNA from the liver of a nontransgenic mouse (lane 12) served as the negative control. ides for the five nontransgenic littermates (three males, two females). The Superose 6 profiles of two of these transgenic offspring yielded cholesterol distributions similar to that of the founder, except that HDL cholesterol was reduced 35 and 20\%, respectively, compared with nontransgenic littermates (data not shown).

In contrast to the above results, plasma from lines expressing lower levels of the variant apo $\mathrm{E}(2.5 \mathrm{or} 21 \mathrm{mg} / \mathrm{dl}$ ) demonstrated a lipoprotein profile that was more like that of nontransgenic mice (Fig. $2 B$ ). In both instances, most of the cholesterol was in HDL. The low expresser (founder 8) had a cholesterol distribution very similar to that typical of nontransgenic mice, with little cholesterol in either the VLDL or IDL fractions. The intermediate expresser (an F1 male offspring of founder 2 with plasma cholesterol of $120 \mathrm{mg} / \mathrm{dl}$ ) had a slightly different profile, with a significant increase in VLDL cholesterol, although much less than that of the high expresser.

Superose 6 fractions representing the major lipoprotein classes (as described in Methods) were pooled, concentrated, and subjected to agarose electrophoresis (Fig. 3). The nontransgenic sample showed typical pre- $\beta$-migrating VLDL (Fig. 3 , lane 1 ) and a slightly slower migrating remnant or IDL species (Fig. 3, lane 2). Likewise, the VLDL fraction from the intermediate expresser was pre- $\beta$-migrating (Fig. 3, lane 3 ). In contrast, the comparable VLDL fraction from the transgenic animal expressing high levels of apo $E$ (Arg-112, Cys-142) had a broad band extending well into the $\beta$-migrating position (Fig. 3 , lane 5 ; compare its migration with IDL, lanes 2,4 , and 6 ). To demonstrate that the $\beta$-migrating lipoproteins from the Superose 6 chromatography were indeed $\beta$-VLDL (i.e., had a density $<1.006 \mathrm{~g} / \mathrm{ml}$ ), both the Superose 6 VLDL fraction and a whole plasma sample of the line 1 mouse were ultracentrifuged and the $d<1.006 \mathrm{~g} / \mathrm{ml}$ top fractions were analyzed by agarose electrophoresis. This analysis showed that $d<1.006$ $\mathrm{g} / \mathrm{ml}$ lipoproteins from either plasma or Superose 6 chromatography were $\beta$-migrating, confirming their identification as $\beta$ VLDL.

Apo $\mathrm{E}$ distribution among plasma lipoproteins was analyzed for both a high-expressing line 1 mouse and an intermediate-expressing line 2 mouse. Pooled Superose 6 fractions rep- 

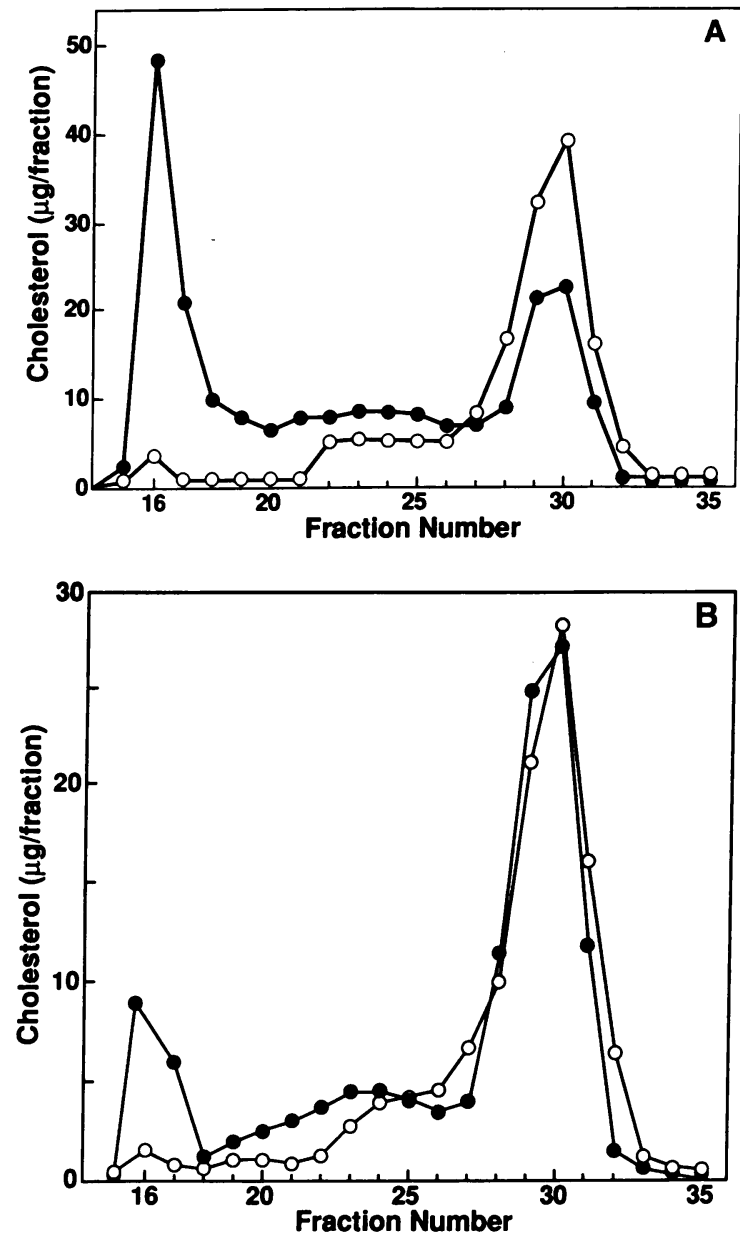

Figure 2. Superose 6 chromatography of $100 \mu 1$ of mouse plasma. The cholesterol distribution of either the transgenic plasma or an equivalent volume of plasma pooled from three nontransgenic littermates was determined as described in Methods. Fractions 15-18, VLDL; fractions 19-22, IDL; fractions 23-26, LDL and $\mathrm{HDL}_{1}$; fractions 27-32, HDL. $(A)$ Transgenic mouse (founder 1; Table I) expressing high levels of apo $\mathrm{E}$ (Arg-112, Cys-142) (•) and nontransgenic littermates $(O)$. (B) Transgenic mouse (F1 male offspring of founder 2; Table I) expressing intermediate levels of apo E(Arg-112, Cys-142) $(\bullet)$ and transgenic mouse (founder 8; Table I) expressing low levels of apo E(Arg-112, Cys-142) (0).

resenting the major lipoprotein classes (as described in Methods) were run on agarose and immunoblotted to detect either mouse or human apo E (Fig. 4). In the line 1 mouse that demonstrated $\beta$-VLDL, mouse apo $\mathrm{E}$ and apo $\mathrm{E}$ (Arg-112, Cys142 ) were present in all fractions and had approximately comparable distributions. In contrast, in the line 2 mouse that did not demonstrate $\beta$-VLDL, human apo $\mathrm{E}$ was underrepresented in the VLDL fraction. Instead, most of the apo E(Arg-112, Cys-142) was on large $\alpha$-migrating particles $\left(\mathrm{HDL}_{1}\right)$, including some of IDL size. Mouse apo E distribution was different, being associated with all lipoprotein fractions, and was especially more abundant on VLDL and typical HDL particles.

The $d<1.006 \mathrm{~g} / \mathrm{ml}$ lipoproteins from the high-expressing line 1 , intermediate-expressing line 2 , and nontransgenic mice were characterized in more detail (Table II). The apolipoprotein content of these lipoproteins was revealed by SDS-PAGE (Fig. 5). As expected, transgenic $d<1.006 \mathrm{~g} / \mathrm{ml}$ lipoproteins

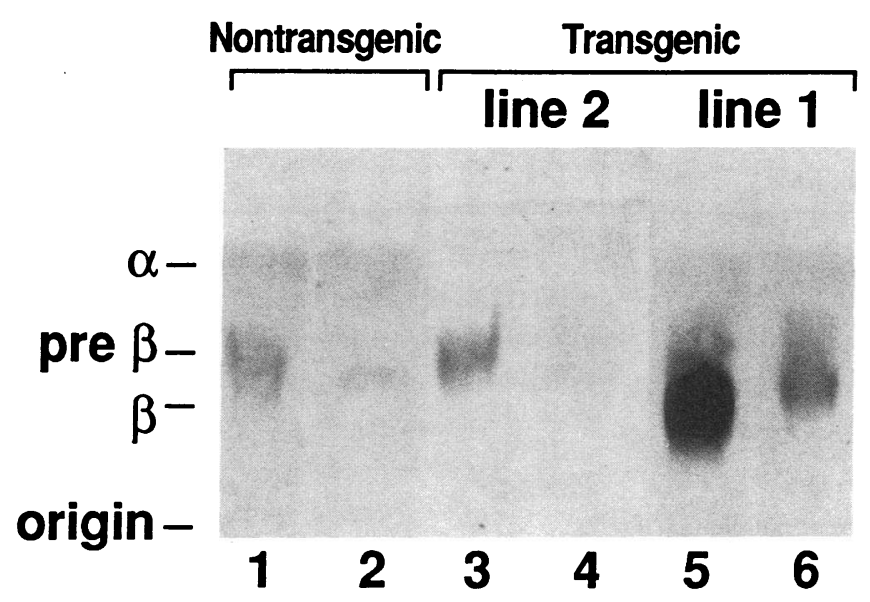

Figure 3. Agarose gel electrophoresis of lipoprotein fractions from a nontransgenic mouse (lanes $l$ and 2 ) and from transgenic mice (lines 1 and 2; see Table I) expressing either intermediate (lanes 3 and 4) or high (lanes 5 and 6) levels of apo E(Arg-112, Cys-142). Lanes 1, 3 , and 5 are Superose 6 fractions 15-18 and lanes 2, 4, and 6 are Superose 6 fractions 19-22 (see Figs. 1 and 2). The origin and migration positions of $\alpha$-migrating (HDL), pre- $\beta$-migrating (VLDL), and $\beta$-migrating (LDL) lipoproteins are indicated.

\section{A Line 1}
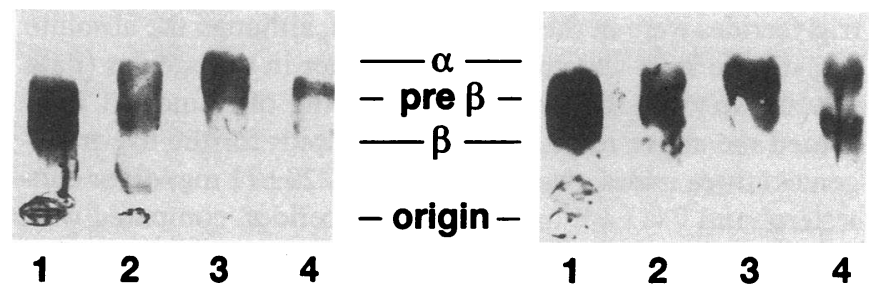

\section{B Line 2}

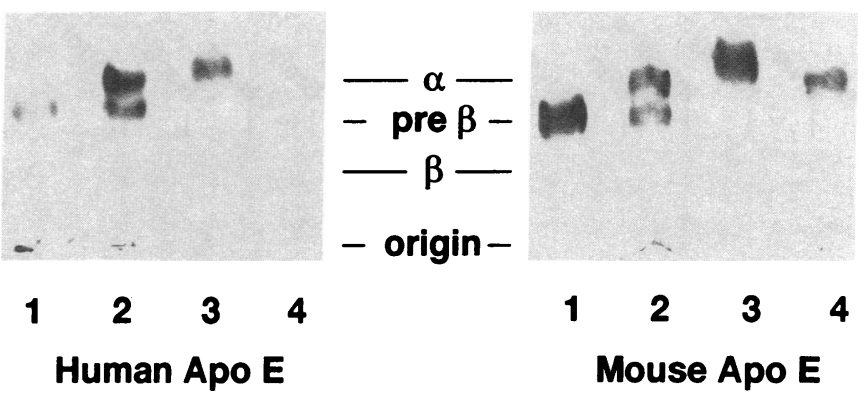

Figure 4. Distribution of apo $\mathrm{E}$ among transgenic mouse lipoproteins. Agarose gel electrophoresis of pooled Superose 6 fractions was performed as described in Methods. Blotted gels of 100- $\mu$ l plasma samples from either a line 1 mouse $(A)$ or a line 2 mouse $(B)$ were incubated first with the human-specific anti-apo $\mathrm{E}$ antiserum (left pan$e l s$, and then stripped with a detergent solution and incubated with the rat-specific anti-apo $\mathrm{E}$ antiserum (right panels). In each instance, the secondary antibody was a horseradish peroxidase-labeled goat anti-rabbit antibody (ECL kit; Amersham Corp., Arlington Heights, IL) and film exposure varied from 1 to $30 \mathrm{~s}$. Lane 1, Superose 6 fractions 15-18 (VLDL); lanes 2, 19-22 (IDL and large $\mathrm{HDL}_{1}$ ); lanes 3, 23-26 (LDL and $\mathrm{HDL}_{1}$ ); lanes 4, 27-32 (HDL). The origin and the migration positions of $\alpha$, pre $\beta$, and $\beta$ lipoproteins are indicated. 
Table II. Characteristics of $d<1.006 \mathrm{~g} / \mathrm{ml}$ Lipoproteins

\begin{tabular}{|c|c|c|c|c|}
\hline & $\frac{\text { Apo E(Arg-112, Cys-142) }}{\text { Normal apo E }}$ & $\frac{\text { Apo B48 }}{\text { Apo B100 }}$ & $\frac{\mathrm{TC}}{\mathrm{TG}}$ & $\frac{\mathrm{CE}}{\mathrm{TC}}$ \\
\hline $\begin{array}{l}\text { Nontransgenic } \\
\text { mouse VLDL } \\
(n=3)\end{array}$ & 0 & $0.7 \pm 0.1$ & $0.09 \pm 0.01$ & $0.08 \pm 0.06$ \\
\hline $\begin{array}{l}\text { Line } 2 \text { transgenic } \\
\text { mouse VLDL } \\
(n=3)\end{array}$ & 2 & $1.1 \pm 0.1$ & $0.10 \pm 0.03$ & $0.21 \pm 0.03$ \\
\hline $\begin{array}{l}\text { Line } 1 \text { transgenic } \\
\text { mouse } \beta \text {-VLDL } \\
(n=4)\end{array}$ & 7 & $2.0 \pm 0.4$ & $0.23 \pm 0.08$ & $0.33 \pm 0.08$ \\
\hline Human $\beta$-VLDL* & & $\neq$ & $0.68^{8}$ & $0.73^{8}$ \\
\hline
\end{tabular}

TC, total cholesterol; TG, total triglycerides; CE, cholesteryl esters.

* Reference 8.

${ }^{\ddagger}$ Not applicable (no apo B48 production in human liver).

${ }^{\S}$ Reference 6.

had human apo E associated with them, while nontransgenic VLDL did not. Densitometric scanning of the Coomassiestained gel indicated that in line $1 \beta$-VLDL (Fig. 5, lane 3), the ratio of apo $\mathrm{E}$ (Arg-112, Cys-142) to mouse apo $\mathrm{E}$ was $7: 1$, while this ratio was only $2: 1$ in line 2 pre- $\beta$-VLDL (Fig. 5 , lane 4 ). This result and the lipoprotein distribution results of Fig. 4 suggest the possibility that a particular threshold ratio of defective to normal apo $\mathrm{E}$ may be required before $\beta$-VLDL will accumulate in plasma. The $d<1.006 \mathrm{~g} / \mathrm{ml}$ lipoproteins from both transgenics and nontransgenics had no apo A-I but appeared to have all the apo C's (data not shown). Because the $d$ $<1.006 \mathrm{~g} / \mathrm{ml}$ lipoproteins from the different transgenic lines had significantly different chemical characteristics (protein and lipid), it was difficult to assess whether there was any significant difference in total apo $\mathrm{C}$ content among these lipoproteins.

Both species of apo B, apo B100 and apo B48, were present in $\beta$-VLDL and normal VLDL, but densitometric scanning

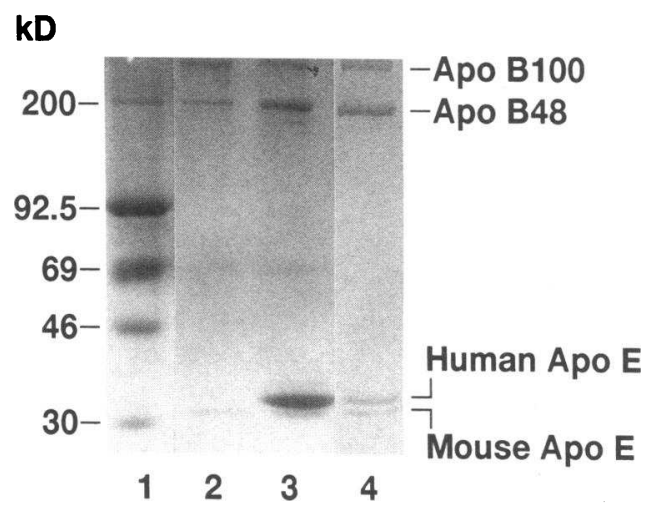

Figure 5. SDS-PAGE of $d<1.006 \mathrm{~g} / \mathrm{ml}$ lipoproteins from a nontransgenic mouse and transgenic mice expressing apo E(Arg-112, Cys-142). Plasma ( $1 \mathrm{ml}$ nontransgenic, $100 \mu \mathrm{l}$ line $1,220 \mu \mathrm{l}$ line 2) was ultracentrifuged as described in Methods. A 20- $\mu$ l (transgenic) or $40-\mu \mathrm{l}$ (nontransgenic) portion of the $200-\mu \mathrm{l} d<1.006 \mathrm{~g} / \mathrm{ml}$ top fraction was loaded on the gel. This represented relative plasma volumes of nontransgenic/line $1 /$ line $2=20: 1: 2.2$. Lane 1 , molecular mass standards; lane $2, d<1.006 \mathrm{~g} / \mathrm{ml} \mathrm{VLDL} \mathrm{from} \mathrm{a} \mathrm{nontransgenic}$ mouse; lane $3, d<1.006 \mathrm{~g} / \mathrm{ml} \beta$-VLDL from a line 1 mouse; lane $4, d<1.006 \mathrm{~g} / \mathrm{ml} \mathrm{VLDL}$ from a line 2 mouse. The positions of apo B100, apo B48, and apo E are indicated. revealed that the apo $\mathrm{B} 48$ / apo B100 ratio was increased in the transgenic $d<1.006 \mathrm{~g} / \mathrm{ml}$ lipoproteins compared with normal VLDL ( Table II). The relative increase of apo B48 was greater in mice demonstrating $\beta$-VLDL but was still slightly increased even in the intermediate-expressing line 2 mice that did not have $\beta$-VLDL. In humans with type III HLP, the increase in apo B48 can be ascribed to delayed catabolism of intestinal lipoprotein remnants, since apo B48 is made exclusively in the intestine (23), while the liver makes only apo B100. In rodents such as mice, however, the liver produces apo B48-containing lipoproteins in addition to apo B100-containing lipoproteins (24), making the contribution of intestinal lipoproteins more difficult to assess. Nevertheless, the increased apo B48:apo B100 ratio in the apo E(Arg-112, Cys-142) high expressers suggests that there is accumulation of apo B48-containing lipoproteins, similar to what occurs in humans with type III HLP.

The lipid content of the $d<1.006 \mathrm{~g} / \mathrm{ml}$ lipoproteins was also investigated (Table II). In spite of the markedly elevated triglycerides, the cholesterol/triglyceride ratio in transgenic mouse $\beta$-VLDL was more than doubled compared with that of normal or of line 2 pre- $\beta$-VLDL. However, the cholesterol enrichment of the transgenic mouse $\beta$-VLDL was less than that of $\beta$-VLDL from human subjects expressing the apo $\mathrm{E}$ (Arg-112, Cys-142) variant (Table II). Both line 2 pre- $\beta$-VLDL and line $1 \beta$-VLDL had a higher percentage of total cholesterol as cholesteryl esters than did normal mouse VLDL, with more cholesteryl ester enrichment occurring in transgenic mouse $\beta$ VLDL. However, the cholesteryl ester content was still lower than that of $\beta$-VLDL from the human subjects (Table II).

A functional defect of the transgenic mouse $\beta$-VLDL was shown in plasma clearance experiments of injected, radiolabeled $d<1.006 \mathrm{~g} / \mathrm{ml}$ lipoproteins (Fig. 6). Normal nontransgenic mouse VLDL was removed from the plasma of normal mice more rapidly than transgenic mouse $\beta$-VLDL ( 66 vs. $36 \%$ of the injected dose at $15 \mathrm{~min}, P<0.001$ ). Accordingly, liver uptake of nontransgenic VLDL was more than that of transgenic $\beta$-VLDL ( 42 vs. $18 \%$ of injected dose at $15 \mathrm{~min}, P$ $<0.001)$. These results directly demonstrate the impaired catabolism of mouse lipoproteins carrying the human apo $\mathrm{E}$ (Arg-112, Cys-142) variant.

\section{Discussion}

On a normal chow diet, transgenic mice that express high levels of the human apo E(Arg-112, Cys-142) variant develop lipoprotein abnormalities very similar to those of type III HLP, including the hallmark characteristic $\beta$-VLDL. This occurs even though, unlike humans, mice normally transport $\sim 80 \%$

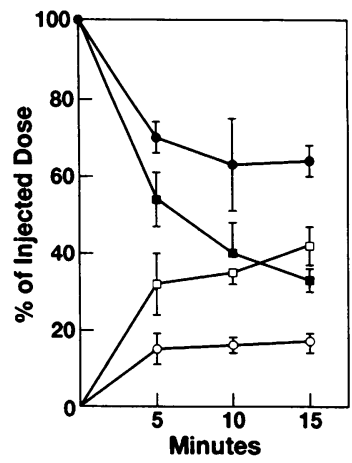

Figure 6. Plasma clearance (filled symbols) and liver uptake (open symbols $)$ in normal mice of nontransgenic $d<1.006 \mathrm{~g} / \mathrm{ml}$ VLDL $(\mathrm{m}, \square)$ and transgenic $d<1.006 \mathrm{~g} / \mathrm{ml} \beta$-VLDL from mice (line 1; see Table I) expressing high levels of apo $\mathrm{E}$ (Arg-112, Cys-142) $(\bullet, 0)$. Data are presented as the mean $\pm \mathrm{SD} ; n=3$ for $5 \mathrm{~min}, n$ $=4$ for $10 \mathrm{~min}, n=6$ for $15 \mathrm{~min}$. 
of their cholesterol in HDL rather than in the apo B-containing lipoproteins VLDL, IDL, and LDL (25). The severity of the hyperlipidemia in the transgenic mice, especially the hypercholesterolemia, appears to depend on the amount of the apo $E$ variant expressed. Our data suggest that there is a threshold level of apo $E$ (Arg-112, Cys-142) required for accumulation of the abnormal $\beta$-VLDL. Transgenic lines expressing levels of the apo E variant equal to or less than that of endogenous mouse apo $\mathrm{E}$, which is $\sim 5-10 \mathrm{mg} / \mathrm{dl}$ in most strains $(25)$, do not have elevated plasma cholesterol, although apo E-mediated lipoprotein metabolism, especially that of $\mathrm{HDL}_{1}$, is perturbed in these low expressers. ${ }^{2}$ It is noteworthy that transgenic lines expressing low levels of this variant, including line 8 mice in this study, have virtually no human apo E (but a considerable amount of mouse apo E) on VLDL; instead, the human apo $\mathrm{E}$ variant is almost all on $\mathrm{HDL}_{1}$ particles.

The transgenic mice expressing intermediate levels of the human apo E variant $(21 \mathrm{mg} / \mathrm{dl})$ have mildly elevated plasma lipids and VLDL cholesterol but do not demonstrate $\beta$-VLDL. Analysis of the apo $\mathrm{E}$ distribution among lipoproteins and the ratio of human to mouse apo $E$ in the VLDL provides a possible explanation of why these line 2 mice do not accumulate $\beta$.VLDL in their plasma. The underrepresentation of the defective human apo $E$ in the VLDL fraction explains why the ratio of defective human apo $E$ to normal mouse apo $E$ in VLDL is only 2:1, which is less than the overall plasma ratio of $\sim 3$ or 4:1. Apparently, there is not enough of the defective apo $E$ on VLDL to prolong the plasma residence time sufficiently to eventually result in $\beta$-VLDL accumulation. Since human subjects heterozygous for apo $\mathrm{E}$ (Arg-112, Cys-142) have a 3:1 ratio of variant to normal apo $\mathrm{E}$ in the $\beta$-VLDL (8), it is not immediately apparent why a similar ratio in the transgenic mouse VLDL does not lead to $\beta$-VLDL accumulation. However, in the high-expressing line 1 transgenic mice that do accumulate $\beta$-VLDL, the ratio of apo E(Arg-112, Cys-142) to normal mouse apo $E$ is very high and is apparently sufficient to yield the type III HLP phenotype in spite of any obstacles presented by mouse/human species differences.

Analysis of the lipids of the $d<1.006 \mathrm{~g} / \mathrm{ml}$ lipoproteins defines other similarities and differences that are relevant. The line 1 transgenic mouse $\beta$-VLDL is similar to human type III HLP $\beta$-VLDL in that the cholesterol/triglyceride ratio and cholesteryl ester content are higher than in normal VLDL. However, human $\beta$-VLDL is typically more cholesteryl ester enriched than that demonstrated by the transgenic mice (Table II). A likely explanation for the lower level of cholesteryl ester enrichment in the $\beta$-VLDL of transgenic mice is the absence of cholesteryl ester transfer protein (CETP) activity in mouse plasma (26). In humans, CETP facilitates the transfer of cholesteryl esters from HDL to VLDL and LDL (27) and may be the factor that primarily determines the cholesteryl ester content of $\beta$-VLDL. In addition, the lower cholesteryl ester content may be part of the explanation why the intermediate-expressing line 2 mice do not demonstrate $\beta$-VLDL. Also, the total cholesterol/triglyceride ratio in line 2 mice is not different from that in nontransgenic mice and this may be a factor in determining electrophoretic mobility of the lipoprotein. To test the hypothesis that CETP plays a major role in the type III HLP response, we have crossed transgenic mice expressing high levels of cynomolgus monkey CETP (28) with either the high-expressing line 1 apo $\mathrm{E}$ (Arg-112, Cys-142) mice or the intermediate-expressing line 2 mice. In the former case, we expect that mice expressing both transgenes will have $\beta$-VLDL with cho- lesteryl ester content more like that of human $\beta$-VLDL. In the latter case, the addition of plasma CETP activity may be suffcient to yield the type III HLP phenotype in line 2 mice expressing intermediate levels of apo E(Arg-112, Cys-142) levels that are close to those in the human subjects with this variant (6).

The impaired catabolism of transgenic mouse $\beta$-VLDL was demonstrated by plasma turnover studies and is probably the mechanism accounting for accumulation of these lipoproteins in mouse plasma, just as it is the major mechanism for $\beta$ VLDL accumulation in humans with type III HLP (1). These results further implicate the receptor binding-defective apo $\mathrm{E}$ (Arg-112, Cys-142) as the causal agent. Although plasma level differences preclude definitive comparisons, it is noteworthy that transgenic mice overexpressing either rat apo $E$ (6-17 $\mathrm{mg} / \mathrm{dl}$; reference 11$)$ or normal human apo $\mathrm{E}(25-35 \mathrm{mg} / \mathrm{dl})$ (deSilva, H., J. Wang, S. Lauer, K. Weisgraber, R. Mahley, and J. Taylor, manuscript submitted for publication) do not demonstrate either hyperlipidemia or $\beta$-VLDL. Instead, VLDL levels in those mice are reduced and apo B-containing lipoproteins are cleared more rapidly than nontransgenic VLDL $(12,29)$.

The catabolism of the transgenic mouse $\beta$-VLDL will be influenced by both the normal mouse apo $\mathrm{E}$ complement and the presence of apo C's, which are known to modulate apo $\mathrm{E}$ activity on $\beta$-VLDL $(30,31)$. Although we have not yet developed a plasma immunoassay to accurately measure endogenous mouse apo E, immunoblot comparisons with nontransgenic mice suggest that mouse apo E plasma levels are actually increased in the line 1 transgenic mice, and overall are probably at about the same ratio to human apo $\mathrm{E}$ that occurs in the $\beta$-VLDL fraction. This situation would suggest that mouse apo $E$ is accumulating in plasma as a result of delayed clearance of the $\beta$-VLDL particles on which it resides. Although quantitative comparisons of apo $\mathrm{C}$ content have not been made, it appears that no major changes in apo $\mathrm{C}$ content result from the overexpression of the human apo $\mathrm{E}$ variant. Thus, the human apo $\mathrm{E}$ (Arg-112, Cys-142) apparently adds to the protein content of the $d<1.006 \mathrm{~g} / \mathrm{ml}$ lipoproteins without displacing the apo C's.

In human type III HLP, plasma cholesterol and triglycerides are usually about equally elevated and the VLDL-cholesterol/plasma triglyceride ratio is typically $>0.3(1)$, but the apo E(Arg-112, Cys-142) transgenic mice have plasma triglycerides two- to fivefold higher than cholesterol, and thus the diagnostic ratio of $>0.3$ is not achievable. One possible explanation is that the transgenic mice are not strictly fasted overnight, but rather are sampled during the light cycle when they are not eating. However, although this may contribute to the variability among animals, it is unlikely to account for the totality of the higher levels. Another possible explanation for the high triglycerides is that there could be a lipolytic processing defect of the transgenic $\beta$-VLDL. Supporting this possibility is the finding that apo E(Arg-112, Cys-142) has reduced affinity for heparin (8), which could be important in the lipolytic processing of triglyceride-rich lipoproteins. The possible lipolytic processing defect is also a testable hypothesis that we will investigate in these transgenic mice, but it will require comparisons with mice expressing other variants of apo $E$ that would not be expected to have such a defect.

The null apo E mice recently reported by Zhang et al. (13) and Plump et al. (14) are similar to apo E-deficient humans in that they have hypercholesterolemia but only mildly elevated 
triglycerides and are prone to development of atherosclerosis. Apo E-deficient humans have $\beta$-VLDL, but it is not clear whether the null apo $\mathrm{E}$ mice have a comparable lipoprotein species (13). Null apo E mice have both similarities and differences compared with the transgenic mice reported here that express dysfunctional apo $\mathrm{E}$. The major similarity is that both types of mice develop spontaneous hyperlipidemia on normal chow diets. This result emphasizes the central role that apo $\mathrm{E}$ plays in lipoprotein metabolism. The major differences between the null apo $E$ mice and transgenic mice expressing dysfunctional apo $\mathrm{E}$ are: null apo $\mathrm{E}$ mice have a more severe hypercholesterolemia but much less severe hypertriglyceridemia, null apo $\mathrm{E}$ mice have considerably more remnant-sized lipoproteins, and the apo B-containing lipoproteins of null apo $\mathrm{E}$ mice have a very different lipid and protein composition (e.g., presence of apo A-I and apo A-IV; apo B48/apo B100 ratio $>20: 1$; see reference 13). Investigations into the reasons for these differences may provide further insights into the role of apo $\mathrm{E}$ in lipoprotein metabolism. Transgenic mice expressing apo $E($ Arg-112, Cys-142) and other dysfunctional variants of apo $E$ can be expected to be useful animal models for a variety of studies on type III HLP.

\section{Acknowledgments}

We thank S. Simonet, J. Taylor, E. Spangler, and E. Rubin for providing DNA constructs, Y. Horie for help with construct preparation, $L$. Shinto and $\mathrm{K}$. Weisgraber for performing apo $\mathrm{E}$ radioimmunoassays, $\mathrm{J}$. McGuire for the lipoprotein compositional analyses, L. Jach and C. Deevy for graphic arts, K. Humphrey for manuscript preparation, and D. Read for editorial assistance.

This work was supported in part by Program Project grant HL47660 from the National Institutes of Health.

\section{References}

1. Mahley, R. W., and S. C. Rall; Jr. 1989. Type III hyperlipoproteinemia (dysbetalipoproteinemia): the role of apolipoprotein $\mathrm{E}$ in normal and abnormal lipoprotein metabolism. In The Metabolic Basis of Inherited Disease. 6th ed. C. R. Scriver, A. L. Beaudet, W. S. Sly, and D. Valle, editors. McGraw-Hill Inc., New York. 1195-1213.

2. Rall, S. C., Jr., and R. W. Mahley. 1992. The role of apolipoprotein E genetic variants in lipoprotein disorders. J. Intern. Med. 231:653-659.

3. Schaefer, E. J., R. E. Gregg, G. Ghiselli, T. M. Forte, J. M. Ordovas, L. A Zech, and H. B. Brewer, Jr. 1986. Familial apolipoprotein E deficiency. J. Clin. Invest. 78:1206-1219.

4. Mabuchi, H., H. Itoh, M. Takeda, K. Kajinami, T. Wakasugi, J. Koizumi, R. Takeda, and C. Asagami. 1989. A young type III hyperlipoproteinemic patient associated with apolipoprotein E deficiency. Metab. Clin. Exp. 38:115-119.

5. Mahley, R. W., and T. L. Innerarity. 1983. Lipoprotein receptors and cholesterol homeostasis. Biochim. Biophys. Acta. 737:197-222.

6. Havel, R. J., L. Kotite, J. P. Kane, P. Tun, and T. Bersot. 1983. A typical familial dysbetalipoproteinemia associated with apolipoprotein phenotype E3/3. J. Clin. Invest. 72:379-387.

7. Rall, S. C., Jr., Y. M. Newhouse, H. R. G. Clarke, K. H. Weisgraber, B. J. McCarthy, R. W. Mahley, and T. P. Bersot. 1989. Type III hyperlipoproteinemia associated with apolipoprotein E phenotype E3/3. Structure and genetics of an apolipoprotein E3 variant. J. Clin. Invest. 83:1095-1101.

8. Horie, Y., S. Fazio, J. R. Westerlund, K. H. Weisgraber, and S. C. Rall, Jr. 1992. The functional characteristics of a human apolipoprotein $E$ variant (cysteine at residue 142) may explain its association with dominant expression of type III hyperlipoproteinemia. J. Biol. Chem. 267:1962-1968.

9. Gregg, R. E., L. A. Zech, E. J. Schaefer, D. Stark, D. Wilson, and H. B. Brewer, Jr. 1986. Abnormal in vivo metabolism of apolipoprotein $E_{4}$ in humans. J. Clin. Invest. 78:815-821.
10. Weisgraber, K. H. 1990. Apolipoprotein E distribution among human plasma lipoproteins: role of the cysteine-arginine interchange at residue $112 . J$. Lipid Res. 31:1503-1511.

11. Shimano, H., N. Yamada, M. Katsuki, M. Shimada, T. Gotoda, K. Harada, T. Murase, C. Fukazawa, F. Takaku, and Y. Yazaki. 1992. Overexpression of apolipoprotein $E$ in transgenic mice: marked reduction in plasma lipoproteins except high density lipoprotein and resistance against diet-induced hypercholesterolemia. Proc. Natl. Acad. Sci. USA. 89:1750-1754.

12. Shimano, H., N. Yamada, M. Katsuki, K. Yamamoto, T. Gotoda, K. Harada, M. Shimada, and Y. Yazaki. 1992. Plasma lipoprotein metabolism in transgenic mice overexpressing apolipoprotein E. Accelerated clearance of lipoproteins containing apolipoprotein B. J. Clin. Invest. 90:2084-2091.

13. Zhang, S. H., R. L. Reddick, J. A. Piedrahita, and N. Maeda. 1992. Spontaneous hypercholesterolemia and arterial lesions in mice lacking apolipoprotein E. Science (Wash. DC). 258:468-471.

14. Plump, A. S., J. D. Smith, T. Hayek, K. Aalto-Setälä, A. Walsh, J. G. Verstuyft, E. M. Rubin, and J. L. Breslow. 1992. Severe hypercholesterolemia and atherosclerosis in apolipoprotein E-deficient mice created by homologous recombination in ES cells. Cell. 71:343-353.

15. Simonet, W. S., N. Bucay, R. E. Pitas, S. J. Lauer, and J. M. Taylor. 1991. Multiple tissue-specific elements control the apolipoprotein E/C-I gene locus in transgenic mice. J. Biol. Chem. 266:8651-8654.

16. Taylor, J. M., W. S. Simonet, N. Bucay, S. J. Lauer, and H. V. de Silva. 1991. Expression of the human apolipoprotein $\mathrm{E} /$ apolipoprotein $\mathrm{C}$-I gene locus in transgenic mice. Curr. Opin. Lipidol. 2:73-80.

17. Simonet, W. S., N. Bucay, S. J. Lauer, D. O. Wirak, M. E. Stevens, K. H. Weisgraber, R. E. Pitas, and J. M. Taylor. 1990. In the absence of a downstream element, the apolipoprotein $\mathrm{E}$ gene is expressed at high levels in kidneys of transgenic mice. J. Biol. Chem. 265:10809-10812.

18. McLean, J. W., N. A. Elshourbagy, D. J. Chang, R. W. Mahley, and J. M. Taylor. 1984. Human apolipoprotein E mRNA. cDNA cloning and nucleotide sequencing of a new variant. J. Biol. Chem. 259:6498-6504.

19. Fazio, S., Z. Yao, B. J. McCarthy, and S. C. Rall, Jr. 1992. Synthesis and secretion of apolipoprotein $\mathrm{E}$ occur independently of synthesis and secretion of apolipoprotein B-containing lipoproteins in HepG2 cells. J. Biol. Chem. 267:6941-6945

20. Boyles, J. K., C. D. Zoellner, L. J. Anderson, L. M. Kosik, R. E. Pitas, K. H. Weisgraber, D. Y. Hui, R. W. Mahley, P. J. Gebicke-Haerter, M. J. Ignatius, and E. M. Shooter. 1989. A role for apolipoprotein E, apolipoprotein A-I, and low density lipoprotein receptors in cholesterol transport during regeneration and remyelination of the rat sciatic nerve. J. Clin. Invest. 83:1015-1031.

21. Bilheimer, D. W., S. Eisenberg, and R. I. Levy. 1972. The metabolism of very low density lipoprotein proteins. I. Preliminary in vitro and in vivo observations. Biochim. Biophys. Acta. 260:212-221.

22. Hussain, M. M., F. R. Maxfield, J. Más-Oliva, I. Tabas, Z.-S. Ji, T. L. Innerarity, and R. W. Mahley. 1991. Clearance of chylomicron remnants by the low density lipoprotein receptor-related protein $/ \alpha_{2}$-macroglobulin receptor. $J$. Biol. Chem. 266:13936-13940.

23. Kane, J. P. 1983. Apolipoprotein B: structural and metabolic heterogeneity. Annu. Rev. Physiol. 45:637-650.

24. Scott, J. 1990. Regulation of the biosynthesis of apolipoprotein $B_{100}$ and apolipoprotein $\mathrm{B}_{48}$. Curr. Opin. Lipidol. 1:96-103.

25. Lusis, A. J., B. A. Taylor, D. Quon, S. Zollman, and R. C. LeBoeuf. 1987. Genetic factors controlling structure and expression of apolipoproteins $B$ and $E$ in mice. J. Biol. Chem. 262:7594-7604.

26. Jiao, S., T. G. Cole, R. T. Kitchens, B. Pfleger, and G. Schonfeld. 1990 Genetic heterogeneity of lipoproteins in inbred strains of mice: analysis by gelpermeation chromatography. Metab. Clin. Exp. 39:155-160.

27. Tall, A. R. 1990. Plasma high density lipoproteins. Metabolism and relationship to atherogenesis. J. Clin. Invest. 86:379-384.

28. Marotti, K. R., C. K. Castle, R. W. Murray, E. F. Rehberg, H. G. Polites, and G. W. Melchior. 1992. The role of cholesteryl ester transfer protein in primate apolipoprotein A-I metabolism: insights from studies with transgenic mice. Arterioscler. Thromb. 12:736-744.

29. de Silva, H. V., S. J. Lauer, J. Wang, Y. Newhouse, L. Shinto, R. W. Mahley, K. H. Weisgraber, and J. M. Taylor. 1992. Opposing effects of human apolipoproteins $\mathrm{E}$ and $\mathrm{C}$-III in lipoprotein remnant clearance in transgenic mice. Circulation 86:I-471. (Abstr.)

30. Kowal, R. C., J. Herz, K. H. Weisgraber, R. W. Mahley, M. S. Brown, and J. L. Goldstein. 1990. Opposing effects of apolipoproteins $E$ and $C$ on lipoprotein binding to low density lipoprotein receptor-related protein. J. Biol. Chem 265:10771-10779.

31. Weisgraber, K. H., R. W. Mahley, R. C. Kowal, J. Herz, J. L. Goldstein, and M. S. Brown. 1990. Apolipoprotein C-I modulates the interaction of apolipoprotein $E$ with $\beta$-migrating very low density lipoprotein ( $\beta$-VLDL) and inhibits binding of $\beta$-VLDL to low density lipoprotein receptor-related protein. J. Biol. Chem. 265:22453-22459. 